Олена Поліщук, кандидат педагогічних наук, доцент кафедри соиіально-гуманітарних і правових дисциплін

Уманський наџіональний університет садівництва

\title{
СУТНІСТЬ ТА СТРУКТУРА ПРАВОВОЇ КОМПЕТЕНТНОСТІ МАЙБУТНІХ МЕНЕДЖЕРІВ У ВИЩИХ АГРАРНИХ НАВЧАЛЬНИХ ЗАКЛАДАХ
}

У статті конкретизовано сутність та структуру правової компетентності майбутнього менеджера аграрної галузі в умовах університетської освіти. Розглянуто компоненти, що складають структуру правової компетентності.

Обтрунтовано структуру та сутність правової компетентності та вивчено основні компоненти: мотиваційно-ціннісний, когнітивно-комунікативний, практично-діяльнісний. Доведено, щзо правовій компетентності високого рівня відповідає сформована система правових знань, адекватне розуміння правової ситуації, проектованої власної поведінки з урахуванням характеру ситуації, щчо виникла, індивідуальності клієнта або підлеглого.

На основі визначених компонентів та показників охарактеризовано рівні сформованості правовоі компетентності майбутніх менеджерів: високий, середній та низький.

Ключові слова: мотиваційно-ціннісний, когнітивно-комунікативний, практично-діяльнісний, компетенції, студенти вищих аграрних закладів, фахівець.

Табл. 2. Літ. 6.

Olena Polishchuk, Ph. D.(Pedagogy), Associate Professor of the Social and Humanitarian and Law Subject Department, Uman National University of Horticulture

\section{NATURE AND STRUCTURE OF LEGAL COMPETENCE OF FUTURE MANAGERS IN HIGHER AGRICULTURAL EDUCATIONAL INSTITUTIONS}

The current agrarian economy is indireneed of influx of competent managers. Therefore, the heads of agricultural enterprises, specialists and farmers must to have skills in the sphere of management, business, production technology. A competent manager of the agrarian sector must to have the ability of management and entrepreneurial activity, to overcome the stereotypes, solve complex issues, control and adjust their activities, make decisions in the critical or non-standard situations, to encourage other people to work together in order to achieve the goal, allow conflicts and mitigate contradictions, establish business contacts, be able to use innovation, have practical skills in the chosen field of activity, analyze their activities, make the necessary conclusions and to formulate proposals.

The article is concretized the essence and structure of legal competence of the future manager of the agrarian sector in the conditions of university education. The components are considered which constitute the structure of legal competence.

The structure and the essence of legal competence are substantiated and the main components are studied: the motivational-valuable, cognitive-communicative, practical-activity. The author proves that the formed system of legal knowledge, adequate understanding of the legal situation, projected own behavior taking into account the nature of the situation that has arisen, individuality of the client or subordinate is responsible to legal competence of high level.

In order to identify the levels of formation of legal competence of managers in the agrarian sector in the process of vocational training in higher education institution, a cluster analysis of experimental data was conducted. With the help of this analysis it was detect that the legal competence in its dynamics passes three levels: low, medium, and high.

The requirements for qualification of specialists that are considered anticipate the formation on them not only professional knowledge and skills, but also the development of the initiative, ability to work in a team, independently to master knowledge, to think logically, to collect and use the necessary information i.e. the existing qualities of a developed active personality.

Keywords: the motivational and axiological, cognitive-communicative, practice-oriented, competence, the students of higher agricultural institutions, a specialist.

A ктуальність проблеми. Для розкриття сутності та структури правової компетентності майбутнього менеджера в аграрній сфері найбільш важливою $є$ проблема визначення набору компетенцій, якими повинен володіти випускник вищого аграрного навчального закладу, і місця в ньому правової компетентності. 


\section{СУТНІСТЬ ТА СТРУКТУРА ПРАВОВОЇ КОМПЕТЕНТНОСТІ МАЙБУТНІХ МЕНЕДЖЕРІВ У ВИЩИХ АГРАРНИХ НАВЧАЛЬНИХ ЗАКЛАДАХ}

Складність визначення необхідного i достатнього набору компетенцій правової компетентності полягає в тому, що роботодавці не можуть їх науково описати, а викладачі ВНЗ, науковці не готові їх сформулювати. Крім того, компетенції складно уніфікувати: спеціаліст, що займає одну і ту ж посаду на різних підприємствах, повинен володіти різним набором компетенцій.

Аналіз останніх досліджень і публікацій. Для кожного напряму i профілю підготовки визначаються компетенції випускника на основі експертних оцінок, опитування роботодавців, 3 урахуванням кваліфікаційних вимог до посад робітників і службовців $[1 ; 2]$.

У новому поколінні стандартів вищої освіти виділяються дві групи компетенцій випускника:

- універсальні, або загальні, інваріантні для різних професій. До цієї групи належать загальнонаукові, інструментальні, соціальноособистісні та загальнокультурні компетенції;

- предметно-спеціальні, або професійні, необхідні представникам окремих професій. До спеціальних компетенцій відносять загальнопрофесійні і профільно-спеціалізовані.

На думку С. Гуріна, ядро ключових компетенцій утворюють адаптація, соціалізація, інтеграція і самореалізація особистості [3].

I. Сєргеєв виділяє чотири елементарні ключові компетенції:

- інформаційна компетенція виражається в умінні самостійно інтерпретувати, систематизувати, критично оцінювати й аналізувати отриману інформацію з позиції розв'язуваної задачі, робити аргументовані висновки, використовувати отриману інформацію при плануванні і реалізації своєї діяльності в тій чи іншій ситуації, структурувати наявну інформацію, подавати ії в різних формах і на різних носіях, адекватних запитам споживача інформації;

- комунікативна компетенція виражається в умінні самостійно вступати в контакт з будь-яким співрозмовником, ураховуючи його особливості; підтримувати контакт успілкуванні, дотримуючись норми і правила спілкування, у формах монологу та діалогу, а також з використанням засобів невербального спілкування; слухати співрозмовника, проявляючи повагу і терпимість до чужої думки; висловлювати, аргументувати і в культурній формі відстоювати власну думку; стимулювати співрозмовника до продовження спілкування;

- проблемна компетенція, або компетенція щодо вирішення проблем, виражається в уміннях самостійно виявляти проблему в ситуаціях різної інформації; формулювати мету; розділяти мету на ряд послідовних завдань; знаходити альтернативні шляхи і засоби вирішення завдань, у тому числі оцінювати необхідність і масштаби залучення зовнішніх ресурсів; передбачити можливість появи вторинних проблем внаслідок використання зазначених шляхів і засобів; публічно представляти результати; оцінювати ступінь фіксованості проблеми і характер досягнень;

- кооперативна компетенція, або компетенція у співробітництві, виражається в умінні самостійно знаходити партнерів для співробітництва і об'єднуватися з ними в групи; здійснювати колективне цілепокладання i планування; розподіляти завдання і ролі між учасниками групи; здійснювати колективне підведення підсумків, включаючи самооцінку колективної діяльності та її результатів; здійснювати колективну презентацію продукту діяльності групи [4, 30 - 31].

Аграрна економіка зараз гостро потребує притоку компетентних менеджерів. А отже, керівники сільськогосподарських підприємств, фахівці і фермери повинні володіти навичками в сфері менеджменту, бізнесу, технології виробництва. У цьому контексті до найважливіших професійних компетенцій Н. Сєркова відносить: предметну (готовність до діяльності з перетворення різних предметів, наприклад, хімічних речовин, живих організмів, сировини і матеріалів, знань і вмінь); методологічну (готовність використовувати різні методи діяльності); технологічну (готовність до використання різних технологічних процесів); менеджерську (готовність до професійної діяльності, що має організаційний характер); підприємницьку (готовність до професійної діяльності, що має інноваційний характер) [5, 24 $-25 ; 6,38-47]$.

Отже, компетентний менеджер аграрної сфери повинен мати здатність до управлінської та підприємницької діяльності, долати стереотипи, вирішувати складні питання, контролювати i коригувати свою діяльність, приймати рішення в критичних або нестандартних ситуаціях, спонукати інших людей працювати спільно заради досягнення поставленої мети, дозволяти конфлікти i пом'якшувати суперечності, встановлювати ділові контакти, вміти використовувати інновації, володіти навичками практичної роботи в обраній галузі діяльності; аналізувати свою діяльність, робити необхідні висновки і формулювати пропозиції.

Формулювання цілей статті (постановка проблеми). Узгодження компетенцій та компонентів у структурі правової компетентності 


\section{СУТНІСТЬ ТА СТРУКТУРА ПРАВОВОЇ КОМПЕТЕНТНОСТІ МАЙБУТНІХ МЕНЕДЖЕРІВ У ВИЩИХ АГРАРНИХ НАВЧАЛЬНИХ ЗАКЛАДАХ}

майбутнього менеджера діяльності аграрного профілю розкрито у таблиці 1.

Отже, метою статті є необхідність розглянути компоненти, що складають структуру правової компетентності. У структурі правової компетентності майбутнього менеджера діяльності аграрного профілю виокремлено такі компоненти: мотиваційно-ціннісний, когнітивно-комунікативний, практично-діяльнісний.

Виклад основного матеріалу. Мотиваційноціннісний компонент обумовлює й активізує всі інші види діяльності, актуалізує механізми цілепокладання. Він включає мотиви, цілі, потреби у професійному навчанні студента, вдосконаленні, самовихованні, саморозвитку, ціннісні установки актуалізації у професійній діяльності, стимулює творчий прояв особистості у професійній діяльності та повсякденному житті. У процесі правової освіти студенти повинні отримати уявлення про такі правові цінності: самовизначення особистості, повага до прав і свобод людини, повага до людської гідності, повага до інститутів громадянського суспільства, повага до норм і правил сучасної демократії,

Узгодження компетенцій та компонентів у структурі правової компетентності майбутнього менеджера зовнішньоекономічної діяльності аграрного профілю

\begin{tabular}{|c|c|c|}
\hline Компоненти & $\begin{array}{c}\text { Компетенції у професійній } \\
\text { діяльності }\end{array}$ & Компетенції в галузі права \\
\hline \multirow[t]{3}{*}{$\begin{array}{l}\text { Мотиваційно- } \\
\text { ціннісний }\end{array}$} & $\begin{array}{l}\text { Наявність особистісних і } \\
\text { професійних цінностей }\end{array}$ & $\begin{array}{c}\text { Наявність правових, професійних та } \\
\text { особистісних цінностей }\end{array}$ \\
\hline & Уміння формулювати цілі & $\begin{array}{c}\text { Уміння ставити законні цілі і їх } \\
\text { досягати }\end{array}$ \\
\hline & $\begin{array}{c}\text { Уміння приймати рішення, брати } \\
\text { відповідальність на себе }\end{array}$ & $\begin{array}{l}\text { Уміння приймати рішення відповідно } \\
\text { до закону }\end{array}$ \\
\hline \multirow{8}{*}{$\begin{array}{c}\text { Когнітивно- } \\
\text { комунікативний }\end{array}$} & Базові загальні знання & Знання загального права \\
\hline & Базові знання із професії & Знання професійного права \\
\hline & Комунікативні навички & Освоєння правової лексики \\
\hline & Комп’ютерні навички & Робота в мережі Інтернет \\
\hline & Навички керування інформацією & Пошук і аналіз правової інформації \\
\hline & Уміння працювати з документами & Робота з юридичною документацією \\
\hline & $\begin{array}{c}\text { Уміння оформити результати } \\
\text { своєї діяльності }\end{array}$ & $\begin{array}{c}\text { Уміння оформити результати правової } \\
\text { діяльності }\end{array}$ \\
\hline & Уміння працювати в групах & Розвиток комунікативних якостей \\
\hline \multirow[t]{7}{*}{$\begin{array}{l}\text { Практично- } \\
\text { діяльнісний }\end{array}$} & $\begin{array}{c}\text { Здатність вирішувати професійні } \\
\text { проблеми }\end{array}$ & Уміння вирішувати правові завдання \\
\hline & Здатність приймати рішення & $\begin{array}{c}\text { Володіння правовими методами } \\
\text { вирішення проблем }\end{array}$ \\
\hline & $\begin{array}{c}\text { Уміння виражати почуття і } \\
\text { ставлення, критично мислити, } \\
\text { здатність до самокритики }\end{array}$ & $\begin{array}{l}\text { Розвиток мовних навичок, уміння } \\
\text { аргументувати свою точку зору }\end{array}$ \\
\hline & $\begin{array}{c}\text { Здатність застосовувати знання на } \\
\text { практиці }\end{array}$ & $\begin{array}{c}\text { Уміння орієнтуватися в загальному і } \\
\text { професійному законодавстві }\end{array}$ \\
\hline & Здатність до навчання & $\begin{array}{c}\text { Уміння знаходити правову інформацію, } \\
\text { володіти навичками застосування } \\
\text { загального професійного права }\end{array}$ \\
\hline & Здатність до ініціативи & $\begin{array}{c}\text { Здійснення правової ініціативи у } \\
\text { професійній сфері }\end{array}$ \\
\hline & $\begin{array}{c}\text { Уміння приймати нестандартні } \\
\text { рішення, вирішувати проблемні } \\
\text { ситуації }\end{array}$ & $\begin{array}{c}\text { Уміння діяти відповідно до закону, } \\
\text { володіння методикою роботи із } \\
\text { законодавчими актами }\end{array}$ \\
\hline
\end{tabular}




\section{СУТНІСТЬ ТА СТРУКТУРА ПРАВОВОЇ КОМПЕТЕНТНОСТІ МАЙБУТНІХ МЕНЕДЖЕРІВ У ВИЩИХ АГРАРНИХ НАВЧАЛЬНИХ ЗАКЛАДАХ}

справедливість, рівність людей перед законом, суспільні блага, повага до національних традицій і культури, загальнолюдських цінностей, цінність політичної багатоманітності, патріотизм, готовність до розумного компромісу, толерантність, правдивість та ін.

Таким чином, формування мотиваційноціннісного компонента у студентів починається iз засвоєння цінностей особистістю, тобто відбувається формування ціннісного ставлення до права та законодавства, переоцінка цінностей, осмислення свого місця і ролі у світі.

Когнітивно-комунікативний компонент безпосередньо пов'язаний із знаннями та особистими якостями студентів: сприйнятливістю до правової інформації, комунікативністю, умінням планувати свою діяльність, здатністю критично оцінювати іiі результати тощо, застосовувати правові знання (у галузі прав людини і громадянина) у вирішенні професійних ситуацій, аргументовано висувати думки на основі норм права і законодавства (когнітивна складова), брати продуктивну участь у спілкуванні, толерантне сприйняття партнера (комунікативна складова).

У нашій роботі зміст когнітивного складника включає: знання ролі правової підготовки студентів до їхньої майбутньої професійної діяльності; мети та основних завдань управлінської діяльності майбутніми менеджерами; змісту і структури правової діяльності; основних функцій менеджера; різних підходів до оцінки ефективності результатів правової діяльності; причин і характеру трудових спорів, що виникають в економічній сфері. Розвиток когнітивного складника правової компетентності сприяє підвищенню самооцінки, корекції уявлень людини про саму себе.

Практично-діяльнісний компонент є підставою для прояву активності особистості людини, в іiі майбутній професійній діяльності як вияв емоційно-вольової та мотиваційної сфери, це “рушійна сила", що спрямовує діяльність індивіда на творчий професійний розвиток шляхом стимулювання її активності.

Практично-діяльнісний компонент відображає вміння застосовувати майбутнім менеджерам отримані правові знання на практиці, орієнтувати свою поведінку на правові норми, проявляти ініціативність, що виражається в участі в правових акціях, діяльності молодіжних організацій і рухів.

Для підготовки конкурентоспроможних фахівців, які здатні обіймати керівні посади в економічних службах сучасних підприємств, слід ураховувати, що вони, крім професійних фахових вмінь, повинні: ставити цілі і формулювати завдання, пов'язані з реалізацією фахових функцій; знаходити вирішення завдань, у тому числі і нестандартних, що стоять перед економічними службами підприємства; бути готовими до кооперації з колегами і роботи в колективі, знати методи управління роботою виконавців, віднаходити й ухвалювати ефективні управлінські рішення.

Розглянуті вимоги до кваліфікації фахівців передбачають формування у них не лише професійний знань та вмінь, але й розвиток ініціативи, здатності працювати в колективі, самостійно засвоювати знання, логічно мислити, добирати та використовувати необхідну інформацію, тобто наявні якості розвинутої активної особистості.

Отже, практично-діяльнісний компонент виражається в здатності виконувати правову діяльність майбутніми менеджерами на оптимальному рівні активності; умінні навчатися посяганню норм і правил правової діяльності; умінні адекватно орієнтуватися у правовій сфері життя.

Компоненти правової компетентності майбутнього менеджера взаємопов'язані і взаємозумовлені. Виключення 3 правової компетентності будь-якого із зазначених компонентів або зниження рівня їх сформованості тягне за собою зниження успішності, а відповідно i результативності професійної діяльності майбутнього менеджера.

Змістове наповнення компонентів правової компетентності менеджера аграрної сфери (мотиваційно-ціннісний, когнітивно-комунікативний, практично-діяльнісний) представлено в таблиці 2.

Показниками мотиваційно-ціннісного компонента визначаємо: систему соціально-правових цінностей, потреб, почуттів, що мотивують студентів до правової діяльності, формують до них позитивне ставлення, усвідомленість важливості правозахисної та правовиховної діяльності, стійкий інтерес до отримання знань та набуття необхідних умінь.

Показниками когнітивно-комунікативного компонента $\epsilon$ система правових знань, усвідомлення технології професійної правової діяльності, уміння встановлювати міжособистісні зв’язки, узгоджувати свої дії з діями інших суб'єктів права.

Показники практично-діяльнісного компонента - вміння та навички, готовність розв'язувати проблеми правової спрямованості, планувати та організовувати правову діяльність, правова активність, що виявляється в різних сферах діяльності. 
Таблиця 2.

Змістове наповнення компонентів правової компетентності менеджерів аграрної сфери

\begin{tabular}{|c|c|c|}
\hline $\begin{array}{l}\text { Компоненти правової } \\
\text { компетентності }\end{array}$ & $\begin{array}{l}\text { Змістове наповнення компонента правової } \\
\text { компетентності }\end{array}$ & Результат \\
\hline $\begin{array}{c}\text { Мотиваційно- } \\
\text { ціннісний } \\
\text { (особистісно-ціннісне } \\
\text { ставлення до правових } \\
\text { явищ, процесів, подій) }\end{array}$ & $\begin{array}{l}\text { 1) прояв ставлення до закону; права в цілому; } \\
\text { правових вчинків інших; правопорушень і } \\
\text { злочинів, правопорушників, } \\
\text { 2) наявність стійких потреб і мотивів до свідомої } \\
\text { правової діяльності; } \\
\text { 3) прояв стійкого цілеспрямованого пізнавального } \\
\text { інтересу до правової діяльності; } \\
\text { 4) усвідомлення цінності правових аспектів своєї } \\
\text { професійної діяльності; } \\
\text { 5) усвідомлення значущості дотримання норм } \\
\text { професійної етики у взаємовідносинах із клієнтами } \\
\text { і партнерами; } \\
\text { 6) зв’язок правових інтересів з ціннісними } \\
\text { орієнтаціями; інтенсивність емоційних } \\
\text { переживань, вольових зусиль, уваги у процесі } \\
\text { правової діяльності; } \\
\text { 7) потреба у підвищенні рівня правової } \\
\text { компетентності; } \\
\text { 8) готовність особистості до діяльності правового } \\
\text { спрямування }\end{array}$ & $\begin{array}{l}\text { Сформована система } \\
\text { моральних орієнтирів, } \\
\text { що стверджують } \\
\text { гуманістичні цінності; } \\
\text { цінність права як засобу } \\
\text { захисту особистості в } \\
\text { суспільстві і самого } \\
\text { суспільства як такого; } \\
\text { цінність } \\
\text { законослухняності як } \\
\text { способу толерантної } \\
\text { життєдіяльності } \\
\text { особистості }\end{array}$ \\
\hline $\begin{array}{c}\text { Когнітивно- } \\
\text { комунікативний } \\
\text { (система правових } \\
\text { знань та знань про } \\
\text { норми їх застосування, } \\
\text { комунікативність у } \\
\text { розв'язанні правових } \\
\text { ситуацій) }\end{array}$ & $\begin{array}{l}\text { 1) сформованість правових знань (Конституції } \\
\text { України; міжнародних документів про права } \\
\text { людини; законів України; джерел правової } \\
\text { інформації в галузі професійної діяльності) та } \\
\text { вміння їх використовувати, власного правового } \\
\text { статусу і правового статусу партнера, нормативних } \\
\text { правових актів для вирішення різних юридичних } \\
\text { завдань; } \\
\text { 2) сформованість уявлень про найбільш поширені } \\
\text { традиційні і нетрадиційні методики вирішення } \\
\text { правових спорів; } \\
\text { 3) сформованість правових понять і надання } \\
\text { юридичної допомоги при невідкладних справах; } \\
\text { 4) сформованість правових суджень і переконань; } \\
\text { 5) вираженість правової самоосвіти; } \\
\text { 6) комунікативність. }\end{array}$ & $\begin{array}{l}\text { Сформованість системи } \\
\text { знань щодо змісту } \\
\text { професійної діяльності } \\
\text { та методів прийняття } \\
\text { правових рішень }\end{array}$ \\
\hline $\begin{array}{c}\text { Практично- } \\
\text { діяльнісний (правові } \\
\text { вміння й позитивний } \\
\text { соціально-правовий } \\
\text { досвід у правовій } \\
\text { сфері, функціональна } \\
\text { готовність до } \\
\text { соціально-правового } \\
\text { захисту особистості) }\end{array}$ & $\begin{array}{l}\text { 1) грамотне застосування знань у практичній } \\
\text { діяльності; узгодження власної діяльності } \\
\text { нормами права; } \\
\text { 2) уміння діагностувати і здійснювати реальні } \\
\text { правові заходи; } \\
\text { 3) навички використання правових знань; } \\
\text { 4) уміння проводити заходи з правової стабілізації; } \\
\text { 5) свідомий вибір певної лінії поведінки; } \\
\text { 6) застосування правового інструментарію для } \\
\text { вирішення проблемно-правових ситуацій; } \\
\text { 7) правова активність }\end{array}$ & $\begin{array}{l}\text { Сформованість системи } \\
\text { практичних дій щодо } \\
\text { вміння застосовувати } \\
\text { свої права на практиці, } \\
\text { керуючись правовими } \\
\text { нормами, відповідальне } \\
\text { ставлення до прийнятих } \\
\text { правових рішень та їх } \\
\text { наслідків }\end{array}$ \\
\hline
\end{tabular}

Основу для визначення рівнів правової компетентності складають методологічні ідеї та структурно-функціональна ознака: компетентність при переході на інший рівень змінює свою структуру і функції. Вважаємо, що перехід компетентності на більш високий рівень означає не зникнення інтегративних властивостей попереднього рівня, а перетворення їх у більш досконалі.

Беручи до уваги сказане, робимо висновок про те, що чим вище рівень розвитку, тим багатший, досконаліший внутрішніми і зовнішніми зв'язками склад правової компетентності як вид професійної компетентності майбутнього менеджера 


\section{СУТНІСТЬ ТА СТРУКТУРА ПРАВОВОЇ КОМПЕТЕНТНОСТІ МАЙБУТНІХ МЕНЕДЖЕРІВ У ВИЩИХ АГРАРНИХ НАВЧАЛЬНИХ ЗАКЛАДАХ}

зовнішньоекономічної діяльності в аграрній сфері. Розглянемо сутність кожного рівня правової компетентності студентів аграрного університету.

3 метою виділення рівнів сформованості правової компетентності менеджерів зовнішньоекономічної діяльності в аграрній сфері в процесі професійної підготовки у ВНЗ було проведено кластерний аналіз отриманих експериментальних даних, за допомогою якого виявлено, що правова компетентність у своїй динаміці проходить три рівні: низький, середній, високий.

Групу студентів 3 низьким рівнем розвитку правової компетентності характеризують такі особливості.

Мотиваційний-ціннісний компонент $\mathrm{y}$ досліджуваному аспекті характеризується несформованими мотивами щодо майбутньої професійної діяльності. Для студентів 3 низьким рівнем розвитку правової компетентності властива участь у емоціогенних (нереальних) правових ситуаціях. Вирішуючи правові (реальні) ситуації, вони беруть до уваги чинники особистої загрози, наприклад, збиток професійному та особистісному статусам з боку клієнта або підлеглого, відсутність компетентності з боку керівництва та колег.

Когнітивно-комунікативний компонент правової компетентності характеризується такими показниками: правові знання носять побутовий характер, не систематизовані, знання в галузі права поверхові й носять фрагментарний характер; повністю відсутня готовність до використання знань у галузі права в необхідних ситуаціях; невміння використовувати отримані знання на практиці. У студентів - майбутніх менеджерів 3 низьким рівнем розвитку когнітивно-комунікативного компонента правової компетентності - відсутня система спеціальних правових знань; неадекватна самооцінка своїх можливостей і здібностей, яка може бути як завищеною, так і заниженою (і в тому, і в іншому випадку вона може суперечити реальній оцінці); зайва принциповість і прямолінійність у висловлюваннях i судженнях, прагнення; нездатність виділити головну проблему правової ситуації, висувати й обгрунтовувати альтернативне вирішення проблеми. Спостерігається недостатній рівень розвитку організаційно-комунікативних здібностей, небажання зрозуміти партнера по спілкуванню, часом прагматичний стиль діяльності, залежні поведінкові реакції, низький рівень задоволеності і рефлексії власної діяльності.

Практично-діяльнісний компонент представлений системою професійних умінь у галузі права, характеризується відсутністю усвідомленості правової ситуації, що обумовлює іiі нерегульований подальший розвиток i використання неадекватних способів правового вирішення ситуації; нездатність підбирати i аналізувати нормативно-правові документи, труднощі у встановленні і підтримці контакту зі співрозмовником, неправильна оцінка проблемної ситуації, позиції клієнта.

Підсумовуючи вище сказане, уявімо узагальнену характеристику низького рівня правової компетентності. Студентам з цим рівнем властиве неправильне співвідношення об'єктивного і суб'єктивного в правовій ситуації. Приступаючи до аналізу правової ситуації економічного конфлікту, студенти - майбутні менеджери часто не повною мірою усвідомлюють іiі, що призводить до неадекватного вибору шляхів і способів їі дозволу, не прогнозують її результатів, а ведуть пошук методом проб і помилок без достатнього обгрунтування вибору способів дії.

Відсутність знань у галузі права, умінь і навичок управління і вирішення правової ситуації робить цей вибір стійким. Беручи до уваги вищесказане, можна зробити висновок про деструктивний характер професійної діяльності правової компетентності низького рівня.

Перейдемо до розгляду сутності середнього рівня розвитку правової компетентності.

Мотиваційно-иціннісний компонент характеризується такими показниками: часткова сформованість мотивів майбугньої професійної діяльності, запам'ятовування і відтворення навчального матеріалу, у той же час, прагнення до пізнання правових аспектів професійної діяльності менеджерів.

Групу студентів з середнім рівнем розвитку когнітивно-комунікативного компонента вирізняють недостатньо сформовані правові знання: правильне, але неповне розуміння правових аспектів професійної діяльності менеджера; частково сформовані вміння; нездатність досить швидко виділити проблему і способи її вирішення, точно окреслити її рівень; знайти помилки при оформленні документів; утруднення при викладі власної позиції. Характеризується такими показниками: середній рівень імпульсивності, що виявляється у відсутності цілеспрямованості при виникненні нетипових для студента - майбутнього менеджера - правових ситуацій; адекватна в цілому, але вимагає досить багато часу оцінка правової ситуації і своїх можливостей уії вирішенні. Проте, на відміну від низького рівня правової компетентності, студенти середнього рівня відзначаються наявністю добре розвинених 


\section{СУТНІСТЬ ТА СТРУКТУРА ПРАВОВОЇ КОМПЕТЕНТНОСТІ МАЙБУТНІХ МЕНЕДЖЕРІВ У ВИЩИХ АГРАРНИХ НАВЧАЛЬНИХ ЗАКЛАДАХ}

особистісно-професійних якостей, що має значення для правової компетентності.

Рівень володіння практично-діяльнісним компонентом виражається в недостатньому вмінні аналізувати правові ситуації; у помилках при відборі та аналізі нормативно-правових актів, у слабкій правовій активності та функціональній грамотності; недостатніх уміннях і навичках вирішення правових ситуацій; середнім рівнем суб' єктивного контролю, що проявляється, 3 одного боку, в усвідомленні відповідальності за події, що розвиваються, з іншого боку, бажанням пояснити, події, що відбуваються за збігом обставин.

Отже, для правової компетентності менеджера середнього рівня характерна часткова сформованість правових знань, умінь і навичок i, тим не менше, вже усвідомлене управління правовою ситуацією, відповідальне ставлення до власної позиції в ній. Студент характеризується помірною імпульсивністю, заниженою або завищеною самооцінкою. Мотивація недостатньо усвідомлена. Завдання управління і вирішення важкої правової ситуації формулюються 3 усвідомленням не тільки мети, але і мотивів вибору способів іiї досягнення. Вирішення цього завдання здійснюється самостійно, з урахуванням особливостей конкретної обстановки, характеризується критичним осмисленням своєї поведінки у певній ситуації на основі застосування теорії права. В цьому випадку конструктивного вирішення правової ситуації не відбувається, отже, правову компетентність студентів-майбугніх менеджерів зовнішньоекономічної діяльності середнього рівня - не можна вважати конструктивною для професійної управлінської діяльності.

Розглянемо сутність правової компетентності високого рівня.

Високий рівень сформованості правової компетентності характеризується стійкістю, активністю мотиваційно-ціннісного компонента. Відзначається готовність використати отримані знання в галузі права для вирішення правових ситуацій, що виникають.

Студенти 3 високим рівнем розвитку когнітивно-комунікативного компонента правової компетентності характеризуються сформованою системою правових знань: адекватно оцінюють правову ситуацію, бачать змістовну сторону, правильно оцінюють суть, можуть виділити і правовий, і економічний, і психологічний рівень. Відзначається терпимість у відносинах із клієнтами і підлеглими. Характеризується низьким рівнем імпульсивності і тривожності, адекватною самооцінкою, що проявляється у відчутті правової сили та професійної гідності, самоповазі, незворушності і доброзичливості щодо клієнта. Це говорить про наявність у них сформованої системи цінностей, професійних і особистісних пріоритетів.

Практично-діяльнісний компонент характеризується усім розмаїттям і високим рівнем розвитку професійних умінь у галузі вирішення правових ситуацій. Студенти високого рівня сформованості правової компетентності відрізняються узгодженістю і спрацьованістю в міжгруповій взаємодії, а також здібностями швидко визначити проблему та адекватні способи і прийоми і1і вирішення, самостійно і оперативно проводити пошук і аналіз нормативно-правових актів. Вони у змозі доступно і ясно викладати свою точку зору; володіють умінням входити в будь-яку роль, що говорить про високий ступінь комунікативноорганізаторського контролю.

Отже, правовій компетентності високого рівня відповідає сформована система правових знань, адекватне розуміння правової ситуації, проектованої власної поведінки з урахуванням характеру ситуації, що виникла, індивідуальності клієнта або підлеглого.

Вирішення складної правової ситуації супроводжується професійно ціннісними почуттями правової переконаності, професійної гідності, відповідальності за розвиток ситуації, доброзичливості. Мотивація відрізняється стійкою сформованістю. Беручи до уваги вищесказане, можна зробити висновок про креативний i конструктивний характер правової компетентності високого рівня у професійній діяльності.

Правову компетентність студентів - майбутніх менеджерів в аграрній сфері - можна вважати сформованою за наявної єдності всіх компонентів iз розглянутими показниками.

Висновки. Отже, у структурі правової компетентності майбутнього менеджера виокремлюємо такі компетенції (професійні, організаційно-управлінські, проектні, інформаційнокомунікаційні, інформаційно-референтні, ринководослідні, прогностично-аналітичні, культурнопросвітницькі, науково-дослідницькі), компоненти (мотиваційно-ціннісний, когнітивно-комунікативний, практично-діяльнісний) та відповідні показники. На основі визначених компонентів та показників охарактеризовано рівні сформованості правової компетентності майбутніх менеджерів: високий, середній та низький.

\section{ЛІТЕРАТУРА}

1. Полищук Е. А. Особенности процесса 


\section{СУТНІСТЬ ТА СТРУКТУРА ПРАВОВОЇ КОМПЕТЕНТНОСТІ МАЙБУТНІХ МЕНЕДЖЕРІВ У ВИЩИХ АГРАРНИХ НАВЧАЛЬНИХ ЗАКЛАДАХ}

формирования правовой компетентности будущих менеджеров аграрной области в высшей школе / Е.А. Полішук // Ежемесячный научн. журн. “Молодой учёный”. - Казань, 2015. № 4 (84). - C. 608-610.

2. Полімук О. А. Принщипи правовоїпідготовки майбутніх менеджерів вищих аграрних навчальних закладів / О.А. Полішук // // Управління навчальними закладами: теорія, історія, практика: матеріали Всеукр. наук.-метод. семінару. [ред. кол. Кірдан О.Л. та ін.]. - Умань. ФОП Жовтий О. О., 2015.- C.111-114.

3. Гурин С. В. Формирование правовой компетентности будущчого учителя в учебновоспитательном процессе вуза: автореф. дисс. на соискание учен. степени канд. пед. наук: спец. 13.00 .01 "Общзая педагогика и история педагогики” / С. В. Гурин. - Мурманск, 2004. $23 \mathrm{c.}$

4. Назаренко Е.О.До питання про конституиійну реформу державної влади в Україні / E.O. Назаренко // Право України. - 1996. - № 10. C.23.

5. Сергеев И. С. Какреализоватькомпетентностньй подходнаурокеивовнеурочнойдеятельности: прак. пособ. / И. С. Сергеев, В. И. Блинов. - М. . АРКТИ, 2007. - 132 c.

6. Серкова Н. В. Психологические рекомендации к созданию электронных курсов в дистанционном обучении /Н. В. Серкова //Новые информачионные технологии в университетском образовании: междунар. науч.-прак. конф., 17-19 мар. 1999 г.: тезисы. -Новосибирск: [Б. и.], 1999. - С. 42-49.

\section{REFERENCES}

1. Polyschuk, E.A. (2015). Osobennosty protsessa formyrovanyia pravovoi kompetentnosty buduschykh menedzherov ahrarnoi oblasty $v$ vysshei shkole [Features of the process of forming the legal competence of future managers of the agrarian region in higher education]. Monthly scientific journal. "The young scientist”. Kazan, no. 4 (84), pp. 608-610. [in Russian].

2. Polischuk, O.A. (2015). Pryntsypy pravovoi pidhotovky maibutnikh menedzheriv vyschykh ahrarnykh navchalnykh zakladiv [Principles of legal preparation of the Maybutny managers of the agrarian agrarian navigators]. Management of educational institutions: theory, history, practice: materials Allukr. sci. method. workshop. [ed. count Kirdan O.L. etc.]. Uman: FOP Zhovtyy O. O., pp.111-114. [in Ukrainian].

3. Huryn, S.V. (2004). Formyrovanye pravovoi kompetentnosty buduschoho uchytelia $\mathrm{v}$ uchebnovospytatelnom protsesse vuza [Formation of legal competence of the future teacher in the educational process of the university]. Extended abstract of candidate's thesis. Murmansk, 23 p. [in Russian].

4. Nazarenko, E.O. (1996). Do pytannia pro konstytutsiinu reformu derzhavnoi vlady $v$ Ukraini [On the issue of constitutional reform of state power in Ukraine]. The Law of Ukraine. No. 10, p.23. [in Ukrainian].

5. Serheev, Y. S. (2007). Kak realyzovat kompetentnostnyi podkhod na uroke y vo vneurochnoi deiatelnosty [How to implement the competence approach in class and after-hour activities]. Moscov: ARCTI, 132 p. [in Russian].

6. Serkova, N.V. (1999). Psikhologicheskie rekomendatsii $\mathrm{k}$ sozdaniyu elektronnykh kursov $\mathrm{v}$ distantsionnom obuchenii [Psychological recommendations for the creation of e-courses in distance education]. Novye informatsionnye tekhnologii $v$ universitetskom obrazovanii: mezhdunar. nauch.-prak. konf - New information technologies in university education: intern. scientificprak. Conf., March 17-19. 1999: abstracts (pp.4249). Novosibirsk. [in Russian].

Стаття надійшла до редакції 30.01.2018

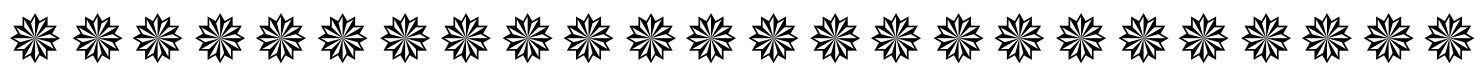

“Жодне бажання не дається тобі оқремо від сили, що дозволяє його здійснити".

Piчард Deйвic Бах американський письменник

“Мистецтво навчання є мистещтво пробуджувати в юних душах допитливість $i$ потім задовольняти й̈.

Анатоль Франс франиузький прозаїк

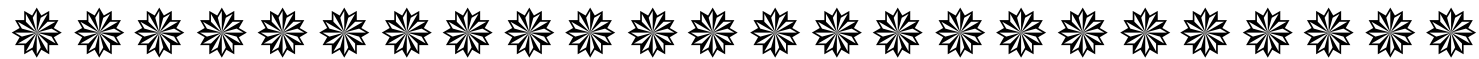

